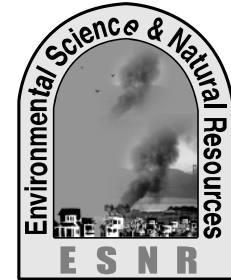

\title{
A Study on Rain Water Harvesting and Comparative Cost Analysis with Withdrawal of Underground Water around Gazipur City
}

\author{
${ }^{1}$ Department of Civil \\ A. M. Ashraful ${ }^{1}$ and M. M. Islam ${ }^{2 *}$ \\ ${ }^{2}$ Department of Environmental Science and Technology \\ Jessore University of Science and Technology, Jessore \\ *Corresponding author: monirul_bau@yahoo.com
}

\begin{abstract}
Rain water harvesting is a technology used to supply water for domestic purposes in developing countries. During dry weather, dust and other pollutants accumulate on the roof surface and are washed off at the beginning of the next rain. The initial contaminated volume of water flowing from a roof after a rain storm is known as the first flush and research has shown that diverting it from the main supply can improve the quality of stored water. An integrated planning for Rooftop Rain Water Harvesting system for different institutes in the premises an educational complex is done. The main objectives of the study are to estimate the roof top rain water harvesting potential and comparative cost analysis with withdrawal underground water.
\end{abstract}

Key words: Cost saving, Dhaka city, Harvesting, Rainwater

\section{Introduction}

Rain water harvesting means collecting rainwater. Roof top rain water harvesting is a system of collecting the rainwater that runs off from every roof.Water harvesting can be applied in many locations in the world but is of particular importance in countries with arid and semiarid lands, where it may often provide the only feasible solution for an improved water supply (Vasudevan, 2002). Its potential very dependent on climate hydrology, landscape, and vegetation (Tafere, 2005). Roof tops and tank systems provide an onsite source of water supply next to homes or public buildings such as university or health centres. Water is our most vital natural resource, supporting life and lifesupport processes. While there is as much as 1,400 million $\mathrm{km}^{3}$ of water on earth, only one-hundredth of $1 \%$ of this amount is easily available for human use. The amount of water available for each person will continue to decrease as the world's populationexpands. Every year, approximately 25 million people die, by either drinking polluted water or because they do not have enough water to meet their daily needs. On primitive scales this usually means an excavated cistern of some kind or perhaps just a banana leaf that empties into a coconut not too sustainable. In the days of the Roman Empire, atrium fed rainwater collection cisterns were common place and to this day an important part of history (Wall et al., 1989). In fact, the art of rainwater collection in the Roman Empire achieved great proportions up until the rule of Caesar and his empress Theodora in the early sixth century AD.

The giant underground cistern in today's Istanbul called Yerebatan Sarayi (Sunken Palace), was used to collect fallen water from the city above in an underground, megalithic and expansive vault with high columns that can be navigated by boat (Gould et al., 1987). Yerebatan Sarayi is certainly the last of its kind, as building a dam can prove to be far more inexpensive. Such as is the case with "Sete Quedas" that once integrated the boarder of Brazil and Paraguay, and was the largest waterfall in the world (now a hydroelectric dam). If the history of rainwater collection tells us anything of value, it is that filtration is the most important key in any harvesting system. Now a day during dry season water is a big problem in Bangladesh. The effect of climate change, unorganized urban development on river bay and discharge of human and industrial waste and new chemicals from industries are key factors that contribute to deteriorating the quality of water and causing severe health hazards. Water quality is directly related to human health, economic activities, ecosystem and biodiversity.

Domestic sewage, industrial waste and agrochemicals hugely pollute the surface water of the Buriganga, Balu and Sitalakkhaya rivers. Various water quality parameters in Bangladesh have deteriorated 16 to 20 times in recent times than those were in 1976 . Industries are mainly polluting water. 60 percent of our contaminated water is created by industrial waste, 30 percent by Dhaka WASA and the rest percentage by Dhaka City Corporation. Seventy percent infant mortality is caused by lack of safe water supply. The design of a sustainable water harvesting system for traditional sloping roof at rural and modern flat roof at urban area is start very recent in Bangladesh. The methodology of the system is that the rainwater is harvested by collecting and storing rain water from a roof top into a large container. Rainwater that falls on a flat roof top it can be storage via a system of pipes. The first flush of rainwater after a dry season should be allowed to run to waste as it will be contaminated with dust, bird droppings etc. 


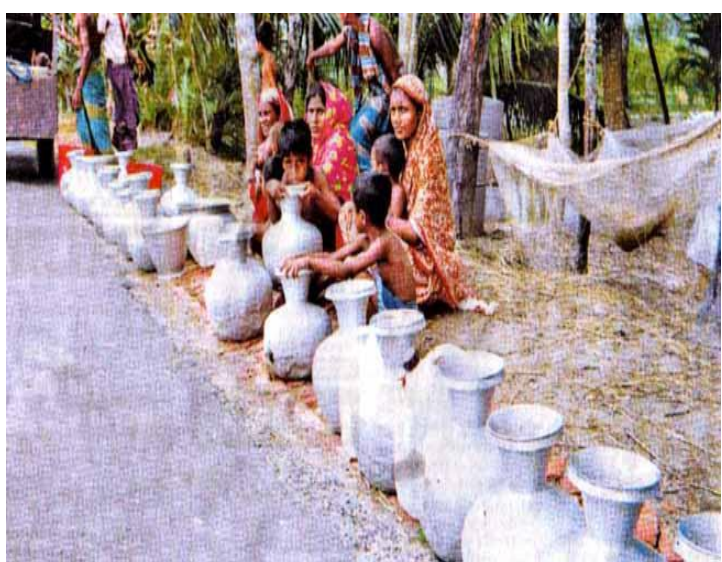

Fig. 1. Waiting for water from NGO

\section{Materials and Methods}

At the rural area in Bangladesh rain water harvesting system is experimentally started by

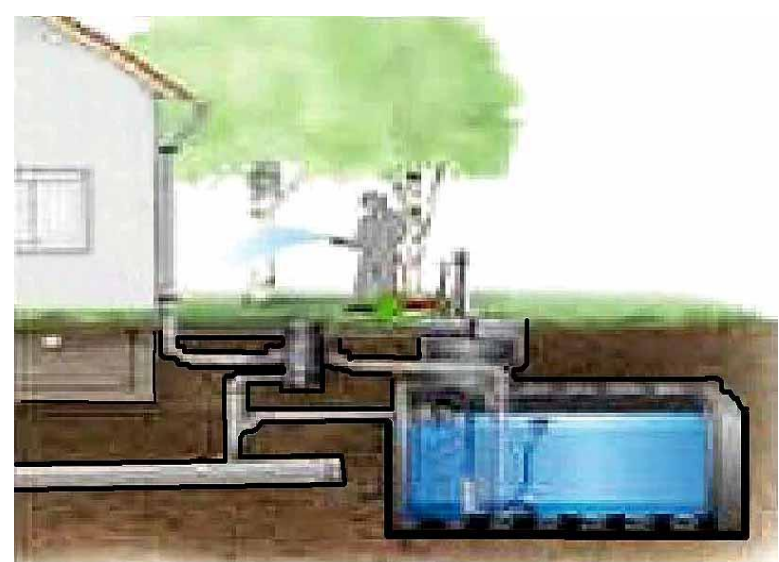

Fig. 2. Rainwater harvesting system at rural area in Bangladesh

different private organization. Forty number of house are still under experiment.
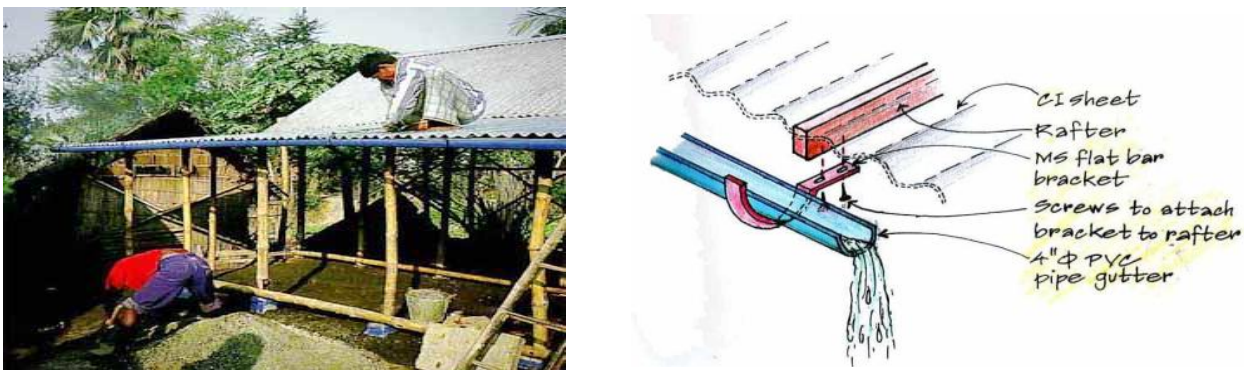

Fig. 3. Rain gutter detail and using in Bangladesh traditional house (ADPC)

\section{Catchment preparation}

Roof provides the catchment surface to collect rainwater. So the roof is to be prepared properly for the easy collection of water. Hence the roof catchment is to be sloped 1:75 as like as truss roof is shown in figure below.

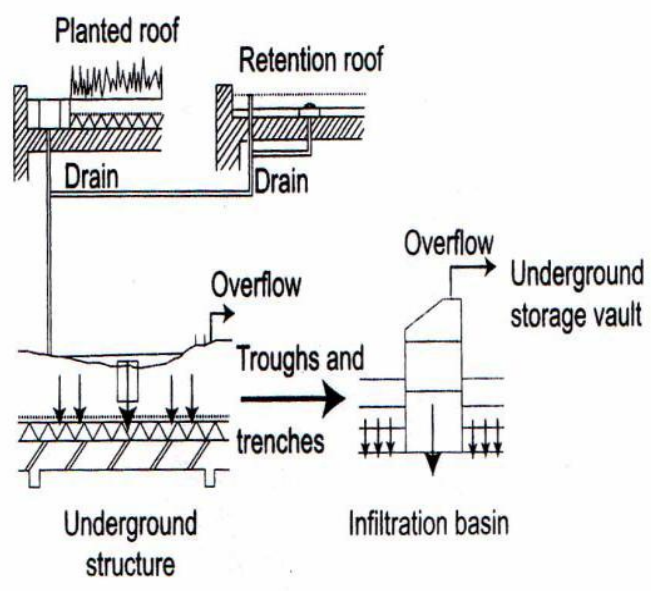

Fig. 4. Rainwater harvesting system

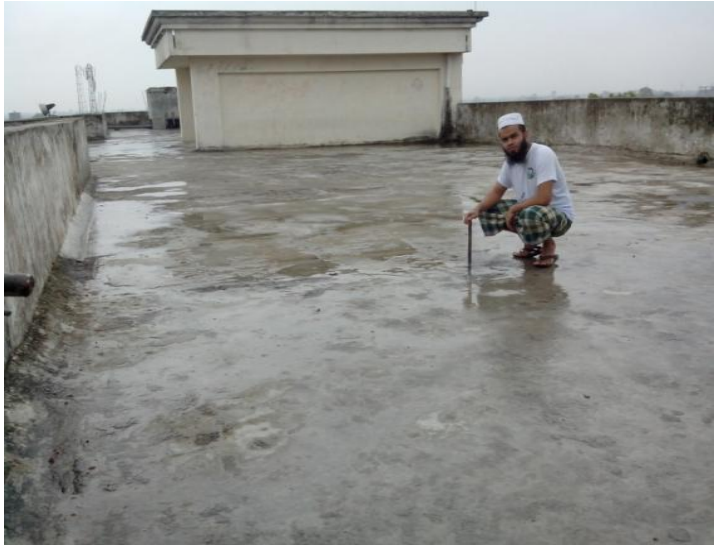

Fig. 5. Roof Catchment in modern building

Table 1. Roof material, run-off coefficient

\begin{tabular}{|l|l|l|l|}
\hline $\begin{array}{l}\text { Area } \\
\text { Description }\end{array}$ & $\begin{array}{l}\text { Runoff } \\
\text { Coefficient } \\
\text { C }\end{array}$ & $\begin{array}{l}\text { Character } \\
\text { of } \\
\text { surface }\end{array}$ & $\begin{array}{l}\text { Runoff } \\
\text { Coefficient } \\
\text { C }\end{array}$ \\
\hline Business & $0.65-0.85$ & Pavement & $0.70-0.85$ \\
\hline Residential & $0.41-0.59$ & $\begin{array}{l}\text { Lawns, } \\
\text { sandy } \\
\text { soil }\end{array}$ & $0.10-0.15$ \\
\hline Industrial & $0.30-0.50$ & $\begin{array}{l}\text { Lawns, } \\
\text { heavy } \\
\text { soil }\end{array}$ & $0.25-0.35$ \\
\hline
\end{tabular}


Table 2. The average temperature and rainfall data of the year of 2013in Gazipur (Source: BMD)

\begin{tabular}{|l|c|c|c|c|c|c|c|c|}
\hline \multirow{2}{*}{ Month } & \multicolumn{9}{|c|}{ Temperature ${ }^{\circ} \mathrm{F}$} & \multicolumn{2}{c}{$\begin{array}{c}\text { Average rainfall } \\
(\mathrm{mm})\end{array}$} & $\begin{array}{c}\text { Average } \\
\text { snow days }\end{array}$ & $\begin{array}{c}\text { Average } \\
\text { fog days }\end{array}$ \\
\cline { 2 - 10 } & \multicolumn{2}{|c|}{ Average } & \multicolumn{2}{c|}{ Absolute } & Daily & Monthly & & \\
\hline & $\max$ & $\min$ & Max & min & & & & \\
\hline January & 77.0 & 52.3 & 87.8 & 42.8 & 0 & 0 & 0 & 2 \\
\hline February & 82.4 & 58.1 & 93.2 & 42.8 & 0.9 & 27 & 0 & 4 \\
\hline March & 91.4 & 66.6 & 102.2 & 55.4 & 1 & 30 & 1 & 1 \\
\hline April & 95.0 & 71.2 & 107.6 & 64.4 & 2.4 & 72 & 1 & 0 \\
\hline May & 93.2 & 71.8 & 107.6 & 66.2 & 3.9 & 117 & 0 & 0 \\
\hline June & 89.6 & 74.3 & 96.8 & 71.6 & 6.1 & 183 & 0 & 0 \\
\hline July & 87.8 & 73.8 & 93.2 & 75.2 & 4.9 & 147 & 0 & 0 \\
\hline August & 87.8 & 75.6 & 96.8 & 73.4 & 4 & 120 & 0 & 0 \\
\hline September & 87.8 & 77.0 & 95.0 & 73.4 & 5.1 & 153 & 0 & 1 \\
\hline October & 87.8 & 69.3 & 93.2 & 62.6 & 1.5 & 45 & 0 & 0 \\
\hline November & 84.2 & 64.8 & 87.8 & 53.6 & 0.3 & 9 & 0 & 3 \\
\hline December & 78.8 & & 84.2 & 44.6 & 0.5 & 15 & 0 & 4 \\
\hline
\end{tabular}

\section{Results and Discussion}

\section{Rainfall calculation}

After knowing the precipitation and the area of the collection surface it is possible to calculate the annual amount of water that can be collected. The formula used for this is as following (The Portland Bureau of Planning and Sustainability, 2010):
Runoff Coefficient x Collection Area $\left(\mathrm{m}^{2}\right)$ x rainfall $\left(\mathrm{mm} \mathrm{month} \mathrm{m}^{-1}\right) / 1000\left(\mathrm{~mm} \mathrm{~m} \mathrm{~m}^{-1}\right)=\mathrm{m}^{3}$ of water month $^{-1}$.

Catchment Area size $=9.15 \mathrm{mx} 40.5 \mathrm{~m}$

Catchment Area $=370 \mathrm{~m}^{2}$

Rainfall Co-efficient, $\mathrm{C}=0.85$

Table 3. Calculation of average rainfall per month

\begin{tabular}{|l|c|c|c|c|c|}
\hline Month & $\begin{array}{c}\text { Monthly } \\
\text { Average } \\
\text { Rainfall } \\
(\mathrm{mm})\end{array}$ & $\begin{array}{c}\text { Runoff } \\
\text { Coefficient } \\
(\mathrm{C})\end{array}$ & $\begin{array}{c}\text { Roof top } \\
\text { area in } \mathrm{m}^{2}\end{array}$ & $\begin{array}{c}\text { Volume of } \\
\text { rain water } \\
\text { per month } \\
\left(\mathrm{m}^{3}\right)\end{array}$ & $\begin{array}{c}\text { Volume of rain } \\
\text { water per month } \\
\text { (liter) }\end{array}$ \\
\hline January & 0 & 0.85 & 370 & 0 & 0 \\
\hline February & 27 & 0.85 & 370 & 8.50 & 8500 \\
\hline March & 30 & 0.85 & 370 & 9.435 & 9435 \\
\hline April & 72 & 0.85 & 370 & 22.64 & 22640 \\
\hline May & 117 & 0.85 & 370 & 36.79 & 36790 \\
\hline June & 183 & 0.85 & 370 & 57.55 & 57550 \\
\hline July & 147 & 0.85 & 370 & 46.23 & 46230 \\
\hline August & 120 & 0.85 & 370 & 37.74 & 37740 \\
\hline September & 153 & 0.85 & 370 & 48.1185 & 48118.5 \\
\hline October & 45 & 0.85 & 370 & 14.15 & 14150 \\
\hline November & 9 & 0.85 & 370 & 2.83 & 2830 \\
\hline December & 15 & 0.85 & 370 & 4.71 & 4710 \\
\hline
\end{tabular}

Total per year rainfall $=288693.5$ liter year ${ }^{-1}$

After taken into consideration the water loss of $5 \%$, the total amount of water that could be collected from the roof would be 274258 liter year ${ }^{-1}$.

\section{Cost analysis for conveyance system}

Total length of 4 inch down pipe $=60 \mathrm{ft}$ (6-storied Total length of 3 inch pipe for rainwater conveyance pipe $=2 \times 130+30=290 \mathrm{ft}$

Total length of 3 inch first flush pipe $=2 \times 60 \mathrm{ft}=120 \mathrm{ft}$ Total length of 1.5 inch pipe for motor to existing water storage tank $=70 \mathrm{ft}$

No. of elbow and tee $=15$ Nos.

Total cost of 4 inch pipe $=60 \times 50=$ TK. 3000 .
Total cost of 3 inch pipe $=290 \times 35=$ TK. 10150

Total cost of 1.5 inch pipe $=70 \times 45=$ TK. 3150 .

Total cost of elbow and tee $=15 \times 70=$ TK. 1050 .

\section{Total cost for conveyance}

system $=3000+10150+3150+1050=$ TK. 17350

Cost Analysis for Motor

Purchasing cost of motor for 1 H.P = TK. 10,000.

Cost analysis for rainwater storage tank

Top slab $=10.335 \times 7.712 \times 3 / 12=20 \mathrm{cft}$

Base slab $=10.335 \times 7.712 \times 5.9 / 12=39.2 \mathrm{cft}$

Side walls $=2(10.335+7.712) \times 6.56 \times 5.9 / 12=116.4 \mathrm{cft}$

Total R.C.C work $=176 \mathrm{cft}$

Dry volume of R.C.C work $=176 \times 1.5=264 \mathrm{cft}$ 
Sum of proportions $=1+2+4=7$

Require of Cement $=\frac{264}{7} \times 0.8=30$ bags $@$ Tk420= 12600

Require of Sand $=\frac{264}{7} \times 2=75 @$ Tk 3 Tk 300

Require of Whoa $=\frac{264}{7} \times 4=150 @ \mathrm{Tk} 9=\mathrm{Tk} 1358$

Require of M.S Rod $=176 \times 1 \% \times 490=862.4 \mathrm{Ib}=$ 0.385Ton@Tk 62,000=Tk 23,870

Total cost of rainwater storage tank $=\mathrm{Tk} .38128$

Total Installation cost of rain water harvesting = Total cost for catchment preparation+ Total cost for conveyance system+ Purchasing cost of motor+ Total cost of rainwater storage tank $=17350+10000+$ $38128=$ TK 65478

\section{Comparative cost analysis}

Existing water supply system cost analysis

Motor related data get from DUET Engineering Office.

Motor hp $=30$

Motor Type=YQS 250-22 KW Motor Rating=22 KW Rated current $=41.8 \mathrm{Amp}$ at 400 Volt and 48.23 Amp at 380 Volt.

Motor Speed $=2900 \mathrm{rpm}$ Rated Voltage $=400 \pm 10 \%$

\section{Overhead intze tank data}

Overhead tank height $=90 \mathrm{ft}$ Depth below ground $=110 \mathrm{ft}$

Capacity of intze tank $=100000$ gallon $=455000$ liter Pumping cost for DUET campus overhead intze tank= Tk. 1940 per day

Capacity of overhead tank $=77580$ litter

Cost of pumping for $=$ Tk. 331 per day

\section{References}

Gould, J. E. and McPherson, H. J. 1987. Bacteriological Quality of Rainwater in Roof and Groundwater Catchment Systems in Botswana, Water International, 12:135-138.

Tafere, M. 2005. Farmers' Response and Willingness to Participate in Water Harvesting Practices: a case study in Dejen district East Gojam zone M.Sc Thesis. Alemaya University, Ethiopia.
Cost analysis for uplifting water of overhead intze tank of each 2000 liter water.

Total height $=110+90=200 \mathrm{ft}=61 \mathrm{~m} \mathrm{~m}=2000 \mathrm{Kg} \mathrm{hr}^{-1}$ $=0.56 \mathrm{Kg} \mathrm{sec}{ }^{-1}$

H.P $=0.61 \mathrm{Hp}$

Motor rating $=0.61 \times 746 / 1000=0.455 \mathrm{KW}$

Cost for pumping per day $=0.455 \times 7.35=$ Tk. 3.34 .

Rainwater supply system cost analysis

Considering storage 1 week of rainwater

Capacity of tank=12120 litter $=12.12 \mathrm{~m}^{3}$

Duration of motor running per week $=1.50$ hour

$\mathrm{H}=70 \mathrm{ft}=21.34=0.75$

$\mathrm{M}=12120 / 1.50$ liter $\mathrm{h}^{-1}=2.24$ liter $\mathrm{sec}^{-1}$

H.P $=0.85$ H.P $\approx 1$ H.P $=0$.

Motor rating $=1 \mathrm{hp} \times 746$ watt $=746$ watt $=0.746 \mathrm{KW}$ Cost for pumping per day $=0.746 \times 7.35 / 7=$ TK. 0.78 . The existing unit cost of water (i.e. TK 3.34 per day) is high as compared to the harvested rainwater price (i.e. TK 0.78 per day). So, if harvested rainwater is used TK. 2.56 will be saved per day.

\section{Conclusions}

This study focused on the appropriateness of rainwater harvesting system for domestic water supply. Rainwater harvesting is a potential source of adequate and reliable water supply, especially in rural areas, in particular, where other water sources are not technically and/or economically feasible. Inadequately designed systems, in terms of storage capacity and catchment area, could only supply water for only a short period after the rainy season, and not the entire dry period.

Vasudevan, L. 2002. A study of biological contaminants in rainwater collected from rooftops in Bryan and College Station [Master"s thesis]. College Station (TX): Texas A. and M. University. p. 180.

Wall, B. H. and McCown, R. L. 1989. Designing Roof Catchment Water Supply Systems Using Water Budgeting Methods, Water Resources Development, 5:11-18. 